\title{
Evaluation of physical and chemical variables of organic substrates in a hydroponic system for strawberry (Fragaria ananassa Duch)
}

\author{
Evaluación de variables físicas y químicas de sustratos orgánicos bajo un sistema \\ hidropónico en fresa (Fragaria ananassa Duch)
}

Elizabeth Marcela Guerrero-Guerrero ${ }^{1}$; Hernando Criollo-Escobar²; German Cháves³; Jorge Alberto Vélez ${ }^{4}$

\begin{abstract}
ARTICLE DATA
1. Researcher, M.Sc. Grupo de Investigación Arapaima, Servicio Nacional de Aprendizaje-SENA. Putumayo, Colombia. marcelitag2@yahoo.es

2. Associate professor. Ph.D., Universidad de Nariño, Pasto, Colombia. hcriolloescobar@gmail.com

3. Associate professor. M.Sc., Universidad de Nariño, Pasto, Colombia. g-ch-j@hotmail.com

4. Associate professor. Ph.D., Universidad de Nariño, Pasto, Colombia. jvelezlozano@gmail.com
\end{abstract}

Cite: Guerrero-Guerrero, E.M.; Criollo-Escobar, H.; Chavés, G.; Vélez, J. (2021). Evaluation of physical and chemical variables of organic substrates in a hydroponic system for strawberry (Fragaria ananassa Duch). Revista de Ciencias Agrícolas. 38(2): 50-62

doi: https://doi.org/10.22267/rcia.213802.158

Received: February 182020

Accepted: May 202021.

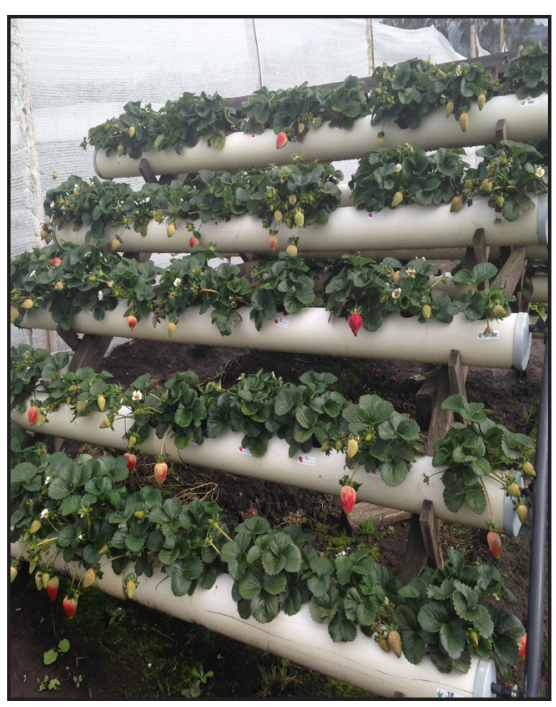

\section{ABSTRACT}

This project is presented as an innovative and clean alternative that optimizes the use of small areas for strawberry (Fragaria ananassa Duch) production in the department of Nariño. This research was conducted at the Centro Internacional de Producción Limpia Lope -SENA- Regional Nariño, with the aim of evaluating physical and chemical variables of organic substrates such as coconut fiber, rice husk, and their mixtures for strawberry (Fragaria ananassa Duch) variety Albión production in a hydroponic system. Six treatments and four repetitions were performed; the treatments were $100 \%$ rice husk, $70 \%$ rice husk and $30 \%$ coconut fiber mixture, $50 \%$ of each of the substrates used, a mixture of $70 \%$ coconut fiber and $30 \%$ rice husk, $100 \%$ coconut fiber, and a control in soil with plastic cover. A comparative analysis was made between the average values obtained in the initial stage and the final stage of the experiment, evaluating physical and chemical properties such as bulk density, real density, gravimetric moisture, granulometry, $\mathrm{pH}$, and electrical conductivity. The experiment showed that taking initial and final measurements of the substrates allows adequate monitoring for optimal crop development since a substrate with a high percentage of particles in the sieve $<0.25$, electrical conductivities greater than $2000 \mu \mathrm{S} . \mathrm{cm}-1$, and an increase in bulk density can produce salinization and compaction, negatively impacting the crop.

Keywords: Productive alternatives; urban agriculture; organic substrates; quality of substrates.

\section{RESUMEN}

Este proyecto se presenta como una alternativa innovadora y limpia que optimiza el uso de áreas pequeñas para la producción de fresa (Fragaria ananassa Duch) en el departamento de Nariño, se realizó en el Centro Internacional de Producción Limpia Lope -SENA- Regional Nariño, con el objetivo de evaluar las variables físicas y químicas de los sustratos fibra de coco, cascarilla de arroz y sus mezclas en un cultivo de fresa (Fragaria ananassa Duch) variedad Albión bajo un sistema hidropónico. Se realizaron 
seis tratamientos y cuatro repeticiones, los tratamientos fueron $100 \%$ cascarilla de arroz, mezcla $70 \%$ cascarilla de arroz y $30 \%$ fibra de coco, $50 \%$ de cada uno de los sustratos utilizados, mezcla $70 \%$ fibra de coco y $30 \%$ cascarilla de arroz, $100 \%$ fibra de coco y un testigo en suelo con cobertura plástica. Se realizó un análisis comparativo entré los valores promedio obtenidos en la etapa inicial y la etapa final del experimento, se evaluaron las propiedades físicas y químicas como densidad aparente, densidad real, humedad gravimétrica, granulometría, $\mathrm{pH}$ y conductividad eléctrica. El experimento mostro que realizar mediciones iniciales y finales a los sustratos, permite un adecuado monitoreo para el óptimo desarrollo del cultivo, ya que un sustrato con un alto porcentaje de partículas en el tamiz $<0.25$, conductividades eléctricas mayores a 2000 $\mu \mathrm{S} . \mathrm{cm}^{-1} \mathrm{y}$ el incremento de la densidad aparente, pueden producir salinización y compactación, impactando negativamente el cultivo.

Palabras clave: Alternativas productivas; agricultura urbana; sustratos orgánicos; calidad de sustratos.

\section{INTRODUCTION}

The term "substrate" is used to define any material, natural or synthetic, that replaces the soil and provides support to the plant. A substrate can provide organic nutrients (e.g. compost, turb, etc.) or inorganic (e.g. perlite, agricultural foams, rock wool, etc.). Additionally, it can be a mixture that combines the properties of more than one substrate (Castañares, 2020).

By evaluating the physical properties of a substrate or substrate mixture, one can determine if it meets the minimum requirements for successful plant production (Cabrera, 1999). Currently, the production of ornamental crops in highquality containers requires a knowledge and understanding of the environment and how it is affected by the physical and chemical properties of the substrates (Castañares, 2020). Thus, this system allows intermittently growing different vegetable crops year-round (Castillo, 2017).

One of the main challenges limiting the adequate use and management of substrates in Colombia is a poor knowledge of their hydro-physical properties (Gonzales- Murillo et al., 2005). Hydroponic crops have certain advantages over traditional crops such as better weed, pest, and disease management, and lack of nutrient deficiency or excess, which altogether can improve crop quality, productivity, and precocity, while optimizing the available area (Llanos, 1988).

In Colombian agriculture, strawberry is a relevant crop due to its nutritional and organoleptic properties; furthermore, it is an exotic fruit and represents a promising alternative in the national and international market (Florez and Mora, 2010). The main strawberry-growing departments are Cundinamarca, Antioquia, Cauca, Norte de Santander, Boyacá, and Nariño. The highest producer is Cundinamarca with yields of 58.14 t.ha ${ }^{-1}$ in a crop area of 1,144 ha; on the other hand, the department of Nariño produces 5.2 t.ha $^{-1}$ in 70 ha (AGRONET, 2017).

Hydroponics is an innovative production alternative in Nariño for generating and obtaining healthy, contaminant-free (Jiménez, 2015) products that contribute to food security (Guerrero et al., 2014) and optimize the genetic potential of the plants (Arévalo, 2015). When clean production techniques are not used, strawberry can be affected by neurocysticersosis, caused by Cysticercus cellulosae and Cysticercus bovis, which contaminate the soil through pig feces or poorly decomposed organic amendments (Garcia et al., 2010) and a lack of sanitary control measures (Chaves and Alvarado, 2012).

Given the above, this study evaluated the effect of physical and chemical properties of coconut fiber 
and rice husk substrates and their mixtures on hydroponic strawberry (Fragaria ananassa Duch) production in the municipality of Pasto. This study highlights the importance of measuring the physical and chemical properties of substrates at the initial and final stages of cultivation to improve the production of vegetable crops. Hydroponic strawberry allowed determining the occurrence of changes in the gravimetric humidity, $\mathrm{pH}$, and electrical conductivity of the substrates at the final stage. However, there were no significant changes in the bulk density, real density, porosity, and granulometry between stages one and two.

\section{MATERIALS AND METHODS}

This research was conducted at the Centro Internacional de Producción Limpia Lope SENA located in eastern Pasto (N 01 $12^{\prime} 48^{\prime \prime}$, W $\left.0.77^{\circ} 15^{\prime} 12.9^{\prime \prime}\right)$ at an elevation of $2630 \mathrm{~m}$ a.s.l., with a mean temperature of $12^{\circ} \mathrm{C}$ and mean annual precipitation of $800 \mathrm{~mm}$.

The hydroponic strawberry system was established as described by Guerrero et al. (2014), using two "A" structures with five 4-inch PVC tubes of 2 meters long placed on each side. The tubes were set at a $2 \%$ angle to allow irrigation and drainage. The tubes were perforated every $20 \mathrm{~cm}$ to accommodate a total of 10 plants per tube. This study used an open hydroponic system, in which the drained solution is not reused and infiltrates to the site or is conducted elsewhere (Tüzel et al., 2009; Van-0s, 2009; Massa et al., 2010).

The coconut fiber and rice husk were washed according to the protocol described by Calderon and Cevallos (2001). The rice husk was placed in a tank with water and mixed twice to eliminate tannins and impurities; then, the substrate was left on a plastic surface to oxygenate it and eliminate retained moisture. The coconut fiber was obtained from a commercial provider; it was washed in a container with abundant water to remove sodium, chlorides, and impurities. Then, the substrate was placed on a plastic surface, covered, and solarized for eight days for disinfection.

The PVC tubes were filled with the different substrates according to each treatment; then, Albion stolons of one month and a half age were transplanted for asexual propagation. Each stolon was disinfected with carbendazim fungicide (i.e., methyl benzimidazol-2-ylcarbamate) at a dose of $1 \mathrm{cc} / \mathrm{L}$ water before planting.

A complete randomized block design was established with six treatments, four repetitions, and four experimental units of 1 liter each. Five tubes were placed on each side of the two structures while a soil bed was established for treatment 6 (T6). The statistical analysis of data was carried out with Analysis of Variance and Tukey test $(<0.05)$, with the use Infostat version 2018. The treatments were compared through a t-test using the measurements of the substrate properties at the start and end of the experiment (i.e., stages 1 and 2, respectively). The porosity of the substrates was determined according to the formula used by Hang (2014). The treatments are described in Table 1.

Table 1. Treatments used to evaluate physical and chemical variables of substrates in hydroponic strawberry (Fragaria ananassa Duch) production.

\begin{tabular}{c|l}
\hline Treatment & \multicolumn{1}{|c}{ Substrate } \\
\hline T1 & Rice husk $100 \%$ \\
T2 & Rice husk 70\% - Coconut fiber 30\% \\
T3 & Rice husk 50\% - Coconut fiber 50\% \\
T4 & Rice husk 30 - Coconut fiber 70\% \\
T5 & Coconut fiber 100\% \\
T6 & Soil control with plastic cover \\
\hline
\end{tabular}


Treatment 6 (soil control with plastic cover) was located next to the hydroponic structure, and the stolons were planted in two rows separated by a distance of $30 \mathrm{~cm}$. Drip irrigation was done, according to Martínez y Leon (2014), in a short but frequent manner. The frequency and duration of the daily irrigation depends on the substrate, crop conditions, and time of year (i.e., season). Fertirrigation was done using a $1 \mathrm{HP}$ electric water pump to deliver the solution from a 50-liter tank to the containers through four drip irrigations per day.

The fertilizer solution was prepared using commercial soluble salts based on the phenological cycle of the strawberry crop and its developmental stage, according to Aguilar-Tlatelpa et al. (2019). The nutritional demand of the variety Albion in a soil-free production system was also considered. Before the application of each solution, the electrical conductivity, $\mathrm{pH}$, and temperature of the substrate were measured with the use of a multiparametric device. Integrated disease and pest management were done according to the requirements of the crop based on monitoring criteria and the use of low-impact products, according to Good Agricultural Practices (Buenas prácticas agrícolas BPA) established in Colombia (ICA-Instituto Colombiano Agropecuario, 2009).

\section{RESULTS AND DISCUSSION}

There were significant differences in bulk density (BD 1) between treatments; the highest outcome was from treatments $\mathrm{T} 5(100 \mathrm{~F})$ and $\mathrm{T} 6$ (soil). Likewise, at stage 2 there were significant differences. Although there were changes in the $\mathrm{BD}$, no significant differences were found between bulk density (BD1) and bulk density (BD2); these values were 0.24 and $0.23 \mathrm{~g} . \mathrm{cm}^{-3}$, respectively (Table 2). Calderon and Cevallos (2001) indicates a bulk density of $0.17 \mathrm{~g} . \mathrm{cm}^{-3}$ for burnt rice husk based on studies conducted in Colombia. This same author also reports values ranging from 0.13 to $0.42 \mathrm{~g} . \mathrm{cm}^{-3}$ based on studies conducted at Universidad Jorge Tadeo Lozano. Moreover, a study reported by Quintero et al. (2006) indicated a bulk density of $0.29 \mathrm{~g} . \mathrm{cm}^{-3}$.

For T5 (100F), the initial bulk density was $0.13 \mathrm{~g} . \mathrm{cm}^{-}$ ${ }^{3}$, and the final was $0.07 \mathrm{~g} . \mathrm{cm}^{-3}$. According to Quintero et al. (2006), coconut fiber has a bulk density ranging from $0.05 \mathrm{~g} . \mathrm{cm}^{-3}$ to $0.4 \mathrm{~g} . \mathrm{cm}^{-3}$; this variation is due to the effect of the moisture content when the coconut fiber is hydrated. Moreover, Quintero et al. (2006) determined a bulk density of $0.14 \mathrm{~g} . \mathrm{cm}^{-3}$ for burnt rice husk, while Belle and Kampp (1994) found values between $0.23 \mathrm{~g} . \mathrm{cm}^{-3}$ and $0.40 \mathrm{~g} . \mathrm{cm}^{-3}$.

Table 2. Physical properties (bulk density -BD, real density - RD) of the substrates at stages 1 and 2 .

\begin{tabular}{|c|c|c|c|c|}
\hline Treatments & $\begin{array}{c}\text { BD stage } 1 \\
\left(\text { g.cm }^{-3}\right)\end{array}$ & $\begin{array}{c}\text { BD stage } 2 \\
\left({\left.\mathrm{~g} . \mathrm{cm}^{-3}\right)}^{-3}\right.\end{array}$ & $\begin{array}{c}\text { RD stage } 1 \\
\left({\left.\mathrm{~g} . \mathrm{cm}^{-3}\right)}^{-3}\right.\end{array}$ & $\begin{array}{c}\text { RD stage } 2 \\
\left(\text { g.cm }^{-3}\right)\end{array}$ \\
\hline $\mathrm{T} 1$ (100C) & $0.10 \mathrm{a}$ & $0.11 b$ & $1.69 c$ & $1.08 \mathrm{a}$ \\
\hline T2 (70H30F) & $0.09 a$ & $0.13 \mathrm{~b}$ & $1.64 c$ & $1.44 \mathrm{c}$ \\
\hline T3 (50H50F) & $0.09 a$ & $0.12 b$ & $1.53 b$ & $1.13 \mathrm{a}$ \\
\hline $\mathrm{T} 4(30 \mathrm{H} 70 \mathrm{~F})$ & $0.10 \mathrm{a}$ & $0.15 b$ & $1.94 \mathrm{~d}$ & $1.50 \mathrm{~d}$ \\
\hline T5 (100F) & $0.14 \mathrm{~b}$ & $0.07 \mathrm{a}$ & $1.00 \mathrm{a}$ & $1.31 \mathrm{~b}$ \\
\hline T6 (SOIL) & $0.92 \mathrm{c}$ & $0.82 \mathrm{c}$ & $2.33 \mathrm{e}$ & $2.24 \mathrm{e}$ \\
\hline
\end{tabular}

Different letters indicate significant differences $(p<0.05)$ H: rice husk, F: coconut fiber 
These values are found within the bulk density range reported in Colombia. The results found for rice husk likely differ from previous reports since the husk was not burnt. This agrees with Meneses (2004) who mentions that this variation could be due to the degree of burning or toasting of the husk; furthermore, different studies in Colombia based on burnt rice husk report a bulk density ranging from $0.13 \mathrm{~g} \cdot \mathrm{cm}^{-3}$ to $0.42 \mathrm{~g} \cdot \mathrm{cm}^{-3}$.

According to Rubio (2010) the bulk density of soil is a good indicator of important soil properties such as compaction, porosity, degree of aeration, and infiltration capacity. In turn, these properties influence water and air circulation in the soil, plant establishment processes (emergence and rooting), and soil management. The bulk density affects plant growth due to the effect of soil resistance and porosity on the roots. A high bulk density increases soil mechanical resistance, while soil porosity decreases. Consequently, these changes limit root growth to critical values. The thresholds of the bulk density for root growth vary according to the soil texture and the plant species.

Plant development and growth are limited or delayed by low bulk density values, which are typical of porous, well-aerated soils with good drainage, and root penetration (despite enabling adequate root development). Conversely, high bulk density values are typical of compact soils with deficient aeration and low water infiltration that can cause waterlogging, anoxia, limit root elongation, and penetration to reach necessary water and nutrients (Donoso, 1992).

At stage 1, there were significant differences in the real density (RD1) between treatments; the treatment's lower density was the T5(100F). There were also significant differences in the real density (RD2) between treatments; the treatments with lower density were $\mathrm{T} 1(100 \mathrm{H})$ and $\mathrm{T} 3$ (50H50F). Although there were changes in the RD, no significant differences were found between real density at stage 1 and two; these values were 1.69 and $1.45 \mathrm{~g} . \mathrm{cm}^{-3}$, respectively. Similar results were obtained by Quintero et al. (2006) who reported a real density of $1.9 \mathrm{~g} . \mathrm{cm}^{-3}$ for burnt rice husk and $1.6 \mathrm{~g} . \mathrm{cm}^{-3}$ for coconut fiber. These values represent the highest found from studies in Colombia, and they can be explained by the degree of burning of the husk, which affects its composition, and how the coconut fiber was obtained.

On the other hand, Quintero et al. (2006) and Quintero et al. (2012) reported real density values lower than those found here when evaluating the hydrophysical characteristics (e.g. real density, bulk density, granulometry, and moisture content) of burnt rice husk and coconut fiber substrates and their mixtures. The authors inferred that the real density of burnt rice husk used in Colombia varied between 0.85 and $1.16 \mathrm{~g} . \mathrm{cm}^{-3}$; furthermore, the real density of coconut fiber ranged from 0.50 to $0.51 \mathrm{~g} . \mathrm{cm}^{-3}$.

The real density decreased in most treatments, except for T5 and T6; however, all treatments showed RD similar to the mean value of $1.50 \mathrm{~g} \cdot \mathrm{ml}^{-1}$ reported by Hernández (2009), indicating a good proportion between the mass and volume of the substrate without considering pores and holes. This contributed to an adequate development of the plants, consistent with their phenological cycle.

There were changes in the particle size distribution; no significant differences were found between stages 1 and 2 for the granulometry (Table 3). According to Quintero (2004), burnt rice husk has $72 \%$ of particles of size below 1 $\mathrm{mm}$ before crop establishment, and this is similar to the results reported by Quintero et al. (2006) who found $80 \%$ of particles below $1 \mathrm{~mm}$ in size. However, these results differ from Meneses (2004) who report particles below $1 \mathrm{~mm}$ in burnt rice husk because the percentage of fine particles in a substrate affects the retention capacity. 
Table 3. Granulometry dynamic for the treatments evaluated.

\begin{tabular}{ccccccc}
\hline $\begin{array}{c}\text { Sieve size } \\
\text { (mm) }\end{array}$ & $\begin{array}{ccccc}\text { T1 } \\
\text { 100H (\%) }\end{array}$ & $\begin{array}{c}\text { 70H30F (\%) } \\
\text { T2 }\end{array}$ & $\begin{array}{c}\text { 50H50F (\%) } \\
\text { T0H70F (\%) }\end{array}$ & $\begin{array}{c}\text { T5 } \\
\text { 100F (\%) }\end{array}$ & $\begin{array}{c}\text { T6 } \\
\text { Soil }\end{array}$ \\
\hline 2 & 32.205 & 26.465 & 22.015 & 10.19 & 13.69 & 47.52 \\
1 & 62.455 & 58.68 & 51.955 & 43.15 & 21.035 & 16.76 \\
0.5 & 4.7 & 7.095 & 11.965 & 18.18 & 29.505 & 12.1 \\
0.25 & 0.725 & 4.035 & 8.935 & 15.95 & 24.11 & 9.31 \\
$<0.25$ & 0.47 & 3.925 & 5.495 & 12.705 & 11.695 & 14.31 \\
\hline & & \multicolumn{7}{c}{ Stage 1 } & & \\
\hline 2 & 37.05 & 30.835 & 27.95 & 29.805 & 31.62 & 46.91 \\
1 & 51.3 & 40.195 & 40.935 & 30.255 & 13.725 & 19.19 \\
0.5 & 5.625 & 13 & 12.725 & 18.675 & 38.05 & 12.8 \\
0.25 & 2.285 & 10.125 & 10.06 & 14.255 & 0.535 & 9.69 \\
$<0.25$ & 3.74 & 5.845 & 8.33 & 7.01 & 16.07 & 11.41 \\
\hline
\end{tabular}

Belle and Kampp (1994) found a high percentage of particles greater than $4.8 \mathrm{~mm}$ in burnt rice husk, yet the mean size ranged between 1 and $2 \mathrm{~mm}$, which is greater than the size reported by Quintero et al. (2006).

Regarding previous granulometry reports, Quintero et al. (2006) evaluated burnt rice husk and coconut fiber substrates and their mixtures, determining that burnt rice husk contained $66.4 \%$ of very fine particles between 0.01 and $0.3 \mathrm{~mm}$, while the $65 \%$ rice husk $-35 \%$ coconut fiber mix had $79.8 \%$ of particles between 0.15 and $1.19 \mathrm{~mm}$. Furthermore, the $35 \%$ rice husk and $65 \%$ coconut fiber mix had $89.3 \%$ of particles between 0.15 and $1.19 \mathrm{~mm}$. Lastly, coconut fiber $(100 \%)$ contained $87 \%$ of particles of sizes ranging from 0.6 and $2.3 \mathrm{~mm}$.

Regarding coconut fiber, Arias (2003) found that $60 \%$ of particles were greater than $1 \mathrm{~mm}$; furthermore, Quintero et al. (2006) reported $58.4 \%$ of particles within the same size range in the same substrate.

The granulometric analysis of the substrates at stages 1 and 2 of the experiment indicates changes in its physical properties as the strawberry plants grow and develop. Irrigation causes a certain degree of substrate compaction, leading to reduced pore sizes, increased moisture retention, and reduced air distribution, as confirmed by Ansorena (1994) and Abad (1996). These impacts can affect crop yield in the long-term. Furthermore, the substrate becomes heavier since excess moisture can reduce oxygen levels in air spaces, thus, affecting root growth. Pore size distribution is a key factor influencing the hydrologic status of the substrates (Abad, 1996).

There were significant differences in the gravimetric humidity (GH1) between treatments; the treatment's higher gravimetric humidity was the T5(100F). Comparatively, at stage 2, there were significant differences in the gravimetric humidity (GH2) between treatments; the treatment's higher gravimetric humidity was the T5(100F) (Table 4). There were significant differences in the gravimetric humidity between stages 1 and 2; these values were 102.3 and 351.18 $\%$, respectively. Table 5 shows the porosity of the substrates evaluated. 
Table 4. Physico-chemical properties of the substrates at the initial (1) and final (2) stages of culture.

\begin{tabular}{|c|c|c|c|c|}
\hline Treatment & Description & $\begin{array}{c}\text { GH stages } 1 \\
(\%)\end{array}$ & PH stages 1 & $\begin{array}{c}\text { EC stages } 1 \\
\left(\mu \mathrm{S} . \mathrm{cm}^{-1}\right)\end{array}$ \\
\hline \multicolumn{5}{|c|}{ Stage 1} \\
\hline $\mathrm{T} 1$ & $100 \mathrm{H}$ & $26.22 \mathrm{a}$ & $6.27 c$ & $295.1 \mathrm{a}$ \\
\hline $\mathrm{T} 2$ & $70 \mathrm{H} 30 \mathrm{~F}$ & $56.26 \mathrm{~b}$ & $6.55 c$ & $511.5 b$ \\
\hline T3 & $50 \mathrm{H} 50 \mathrm{~F}$ & $88.71 \mathrm{c}$ & $6.33 c$ & $972.5 d$ \\
\hline $\mathrm{T} 4$ & $30 \mathrm{H} 70 \mathrm{~F}$ & $131.83 d$ & $6.31 c$ & $1387.5 f$ \\
\hline $\mathrm{T} 5$ & $100 \mathrm{~F}$ & $260.52 \mathrm{e}$ & $5.9 \mathrm{~b}$ & $1246 \mathrm{e}$ \\
\hline T6 & Soil & $50.26 \mathrm{~b}$ & $5.45 a$ & $670.5 c$ \\
\hline \multicolumn{5}{|c|}{ Stage 2} \\
\hline $\mathrm{T} 1$ & $100 \mathrm{H}$ & $151.61 b$ & $4.4 \mathrm{~b}$ & $1852 b$ \\
\hline $\mathrm{T} 2$ & $70 \mathrm{H} 30 \mathrm{~F}$ & $346.29 c$ & $4.36 \mathrm{a}$ & $2278 d$ \\
\hline $\mathrm{T} 3$ & $50 \mathrm{H} 50 \mathrm{~F}$ & $440.28 d$ & $4.73 c$ & $1300 a$ \\
\hline $\mathrm{T} 4$ & $30 \mathrm{H} 70 \mathrm{~F}$ & $499.10 \mathrm{e}$ & $4.28 \mathrm{a}$ & $2834 \mathrm{e}$ \\
\hline $\mathrm{T} 5$ & $100 \mathrm{~F}$ & $633.19 f$ & $4.32 \mathrm{a}$ & $1907 b$ \\
\hline $\mathrm{T} 6$ & Soil & $36.62 \mathrm{a}$ & $5.47 \mathrm{~d}$ & $2010 c$ \\
\hline
\end{tabular}

Gravimetric humidity (GH), $\mathrm{pH}$, electrical conductivity (EC), H: rice husk, F: coconut fiber Different letters indicate significant differences between groups $(\mathrm{p}<0.05)$

The results indicate that, at stage 1, T5 (100F) had the highest water retention (260.52\%), and most particles (29.5\%) were of size $0.5 \mathrm{~mm}$, with $86.45 \%$ porosity. Similarly, at stage 2, T5 (100F) also showed the highest water retention (633.19\%), and most particles (38.05\%) were of size $0.5 \mathrm{~mm}$, with $94.68 \%$ porosity. According to GutiérrezCastorena et al. (2011), coconut fiber (1-2mm) can reach up to $960 \%$ gravimetric humidity, yet it drastically decreases with the addition of inorganic matter such as pumice, reaching as low as $140 \%$. Mixing coconut fiber with other substrates directly affects water retention, regardless of the particle size. Moreover, water retention also varies according to particle size; for instance, coconut fiber substrate mixed with pumice has up to $20 \%$ more particles of sizes $2-3 \mathrm{~mm}$ than particles of sizes $1-2 \mathrm{~mm}$.

Overall, the water retention of coconut fiber changes when it is mixed with other substrates, especially, inorganic. Therefore, substrate mixtures most likely perform better using organic substrates such as rice husk. The results found here demonstrate that each substrate mixture reacted differently; furthermore, there was an increase in the percentage of particles of sizes $<0.25 \mathrm{~mm}$ and moisture content. The $\mathrm{pH}$ level decreased in most cases, except in T6, and the electrical conductivity increased in all treatments, while the porosity mostly decreased, except in T5 and $\mathrm{T} 6$. 
Table 5. Porosity of the substrates and their mixtures.

\begin{tabular}{cccc}
\hline Treatment & Description & Porosity stage 1 \% & Porosity stage 2 \% \\
\hline T1 & 100H & 94.32 & 89.86 \\
T2 & $70 H 30 F$ & 94.24 & 90.98 \\
T3 & 50H50F & 94.15 & 89.40 \\
T4 & 30H70F & 94.77 & 90.35 \\
T5 & 100F & 86.45 & 94.68 \\
T6 & Soil & 60.52 & 63.34 \\
\hline
\end{tabular}

Pure coconut fiber with particles of sizes 2-3mm has high water retention (i.e., up to $960 \%$ ) due to its high interparticle pore content (Vence, 2008); however, this moisture is easily released given the presence of compound packing macropores (Hiller, 1998). Regarding inorganic particles, they have simple packing pores and vesicles; the former are continuous and permanent, contributing to good drainage (Or and Wraigth, 2000), while the latter are occluded and do not allow fluid exchange (Lemaire, 1995).

At stage 1, T1 $(100 \mathrm{H})$ showed the lowest water retention $(26.22 \%)$, and the highest percentage (62.455\%) of particles had a size of $1 \mathrm{~mm}$, with $94.32 \%$ porosity. Comparatively, at stage 2, T5 (100F) had the lowest water retention (151.61\%), and the highest percentage (37.05\%) of particles had a size of $2 \mathrm{~mm}$, with $89.86 \%$ porosity. Although there were changes in porosity, no significant differences were found between stages 1 and 2, these values were 87.40 and $86.43 \%$, respectively.

Several studies mention that the physical properties of a substrate must be optimal at crop establishment since these cannot be modified at later stages (Ansorena, 1994; Cabrera, 1999; Vence, 2008). There is an evident need for more basic research to understand these properties and their relationship with particle size, shape, type, and arrangement (Verdonck and Demeyer, 2004). It is especially important to generate knowledge of the pore space between substrate particles (Verdonck et al., 1984), the relationship between inner pores, and moisture content (Orozco et al., 1995), as well as particle distribution (Burés, 1997), type, and arrangement (Beardsell et al., 1979). This knowledge cannot be directly generated through routine methodologies since pores and particle morphology and distribution cannot be directly quantified in a container.

In most research on substrate physical properties, porosity is not directly measured but rather calculated (Horn and Baumgartl, 2000). However, water retention values do not provide information about pore size (Vence, 2008). Moreover, according to Gutiérrez-Castorena et al. (2011), the best response variables in lettuce seedlings were found in substrate mixtures with high coconut fiber content, which display high water retention $(240 \%)$ and $88 \%$ total pore space. In this study, the treatments with the highest coconut fiber content showed the greatest water retention; therefore, the initial and final evaluations allowed determining variations in moisture content to identify the optimal conditions for strawberry plant development.

The results reported by Gutiérrez-Castorena et al. (2011) indicate that pure substrates (organic and inorganic) and mixtures below 50:50, especially those containing particles of $2-3 \mathrm{~mm}$, retain less water between 55 and 70 at tensions of $0-10 \mathrm{~cm}$ 
of the water column. By relating porosity and pore size with the amount of water retained at different water column tensions, the authors determined that coconut fiber mixtures $2-3 \mathrm{~mm}$ particles) with a high number of pores within and between interconnected particles retained more water compared to mixtures with macropores such as in pure inorganic materials, where water retention is lower.

Particle size variation leads to different physical properties (Verdonck and Demeyer, 2004; Anicua et al., 2009), and in mixtures of different types of material, their physical and micromorphological properties are more complex. This is due to differences in the types of pores and functions of organic and inorganic materials (Pape and Lagger, 1994) since their properties vary according to the mixing ratio.

Regarding volumetric humidity, lower particle sizes (1-2mm) for organic and inorganic materials reduce the water retention capacity since the total pore space is also lower (Anicua et al., 2009).

Physical properties of substrates are associated with the proportion of each particle type (i.e., greater water retention for coconut fiber and greater percolation for pumice). Therefore, there is a direct relationship between gravimetric humidity and particle size. Bunt (1992) mentions that to increase the aeration capacity of a substrate, thick organic material must be added to the mixture; however, the author did not consider inorganic particles that can also retain moisture at lower proportions. In this study, T4 and T5 had higher coconut fiber content and, therefore, retained more water. Accordingly, an alternative solution to reduce moisture retention would be to mix the coconut fiber with inorganic or organic substrates that favor drainage.
At stage 1, there were significant differences in $\mathrm{pH}$ between treatments. The treatments with higher $\mathrm{pH}$ were T1(100H), T2(70H30F), T3(50H50F), and $\mathrm{T} 4(30 \mathrm{H} 70 \mathrm{~F})$; likewise, at stage 2 , there were significant differences too. The treatment with higher pH was T6 (soil) (Table 4). There were significant differences in $\mathrm{pH}$ between stages 1 and 2 ; these values were 6.13 and 4.59 , respectively.

The root system of the strawberry plant is located within the first $15 \mathrm{~cm}$ of the soil. Particularly, the soil should be shallow, light, and preferably sandy, with good drainage, good fertility, and a pH range from 5.7 to 6.5 (Hancock et al., 2008); however, strawberry generally grows in different soil types (Demchak et al., 2013).

Regarding substrate $\mathrm{pH}$, Abad et al. (2005) considered that an adequate $\mathrm{pH}$ for the saturation extract of the substrates should range from 5.2 to 6.3 since the nutritional elements are more assimilable within this range. Additionally, these authors mention that salinity, measured as EC, is adequate for most plants within a range of 2.00 to $3.49{\mathrm{dS} . \mathrm{m}^{-1}}^{-}\left(2000\right.$ to $\left.3490 \mu \mathrm{S} . \mathrm{cm}^{-1}\right)$. Values above $5000 \mu \mathrm{S} . \mathrm{cm}^{-1}$ are harmful to plants.

At stage 1, there were significant differences in the electrical conductivity (EC1) between treatments; the treatment with lower electrical conductivity was $\mathrm{T} 1(100 \mathrm{H})$. At stage 2, there were significant differences in the electrical conductivity (EC2) between treatments; the treatment with lower electrical conductivity was T3(50H50F). There were significant differences in electrical conductivity between stages 1 and 2; these values were 847.18 and $2030.16 \mu{\mathrm{S} . \mathrm{cm}^{-1}}^{-1}$, respectively.

According to Molina (2018), the optimal electrical conductivity for strawberry is $2000 \mu \mathrm{S} . \mathrm{cm}^{-1}$; therefore, caution should be taken with substrates that have higher electrical conductivity levels, so normal crop development is not affected. 
Torres et al. (2000) states that nutritional problems are among the main causes of low production quality and plant loss in greenhouses and nurseries. Therefore, $\mathrm{pH}$ and EC monitoring for growth media allows solving nutritional issues before crops are affected. The $\mathrm{pH}$ of growth substrates affects nutrient availability, especially, micronutrients. Electrical conductivity is a measure of the concentration of dissolved salts in a growth media; therefore, EC values provide an estimate of the amount of fertilizer available in the media for plant growth.

Castellanos and Borbón (2009) evaluated substrates with and without recirculation and found that the EC of the drainage increased up to $2600 \mu \mathrm{S} . \mathrm{cm}^{-1}$ by the end of the cycle. This finding is due to the progressive accumulation of salts in a substrate due to evapotranspiration. Therefore, after the application of nutritive solution, excess drainage can remove a fraction of the salts from the substrate.

According to Ansorena (1994), the substrate is a source of nutrients by cationic exchange, which, in turn, greatly depends on the $\mathrm{pH}$. Consequently, it is important to characterize chemically substrates and nutritional aspects of the plant.

Knowledge about the physical and chemical properties of soil and substrates such as bulk density, real density, gravimetric humidity, granulometry, $\mathrm{pH}$, and electrical conductivity, allows a clearer understanding of how these properties change throughout cultivation. Accordingly, measuring these substrate properties can reduce crop development risks.

\section{CONCLUSIONS}

The evaluation of the coconut fiber and rice husk substrates and their mixtures in hydroponic strawberry allowed determining the occurrence of changes in the gravimetric humidity, $\mathrm{pH}$, and electrical conductivity of the substrates at the final stage. However, there were no significant changes in the bulk density, real density, porosity, and granulometry between stages one and two.

The experiment demonstrated that measuring the initial and final properties of the substrates allows adequate monitoring to achieve optimal strawberry development since an electrical conductivity greater than $2000 \mu \mathrm{S} . \mathrm{cm}^{-1}$ can produce salinization and compaction, which negatively affects the crop.

Overall, the use of substrates for hydroponic strawberry production in Nariño is an innovative and competitive alternative in reduced spaces and degraded soil, allowing small-scale growers to improve their quality of life through technological implementation.

\section{CONFLICT OF INTEREST}

The authors declare that there is no conflict of interest.

\section{BIBLIOGRAPHIC REFERENCES}

Abad, M.; Noguera, P.; Carrion, C. (2005). Sustratos para el cultivo sin suelo u fertirrigacion. En Cadahía, C. Fertirrigacion de cultivos hortícolas, frutales y ornamentales. 3ra ed. Ed. Madrid, España: Mundiprensa. 681p.

Abad, M. (1996). Sustratos: propiedades y manejo de materiales orgánicos, minerales y sintético inertes y activos. In: Rodríguez, A. Hidroponía: una esperanza para Latinoamérica, Curso Taller Internacional. Lima, Perú: Universidad Nacional Agraria La Molina, Centro de Investigación de Hidroponía y Nutrición Mineral. 65p.

Aguilar-Tlatelpa, M.; Volke, V.; Sánchez, P.; Pérez, M.; Fajardo, M. (2019). Concentración y extracción de macronutrimentos en cuatro variedades de fresa. Revista Mexicana de Ciencias Agrícolas. 10(6):12871299. doi: https://doi.org/10.29312/remexca. v10i6.1552 
Agronet - Red de información y comunicación del sector agropecuario. (2017) Red de Información y Comunicación del Sector Agropecuario de Colombia 2017. Sistema de reportes y estadísticas. Recovered from https://www.agronet.gov.co/Documents/34FRESA_2017.pdf

Ansorena, M. J. (1994). Sustratos, propiedades y caracterización. España: Mundi Prensa. 172p.

Arias, M. ( 2003). Utilización agrícola de los derivados del mesocarpo del coco. Bogotá: Facultad de ingeniería. Universidad Nacional de Colombia. 11p

Anicua, S.; Gutiérrez, C.; Sánchez, G.; Ortiz, S.; Volke, H.; Rubiños, J. (2009). Tamaño de partícula y relación micromorfológica en propiedades físicas de perlita y zeolita. Agricultura Técnica en México. 35(2): 147156.

Arévalo, G. (2015). Determinación de la eficiencia de manejo de nutrientes y agua en tres variedades de pimiento de color (Capsicum annum) bajo hidroponía en condiciones de invernadero en Mulacagua, departamento de Comayagua, Honduras. Recovered from https://dialnet.unirioja. es/servlet/tesis?codigo=111599

Beardsell, D.; Nichols, D. G.; Jones, D. L. (1979). Physical properties of nursery potting-mixtures. Scientia Horticulturae. 11: 1-8.

Belle, S.; Kampp, N. (1994). Utilización de la cascarilla de arroz carbonizada como acondicionador hortícola para un suelo orgánico. Pesquisa Agropececuaria Brasileira. 29(8): 1265-1271.

Bunt, A.C. (1992). Media and mixes for container - grown plants. London, Great Britain: Unwin hyman. 13p

Burés, S. (1997). Sustratos. Madrid, España: Ediciones Agrotécnicas. 342p.

Cabrera, R. I. (1999). Propiedades, uso y manejo de sustratos de cultivo para la producción de plantas en maceta. Revista Chapingo Serie Horticultura 5(1):5-11. doi:10.5154/r.rchsh.1998.03.025

Calderon, F; Cevallos, F. (2001). Los sustratos. Recovered from http://www.drcalderonlabs.com/ Publicaciones/Los_Sustratos.htm
Castellanos, J.; Borbón, M. (2009). Panorama de la horticultura protegida en México. En: Castellanos, J. Z. Manual de Producción de Tomate en Invernadero. (ed). pp: 1-18. Guanajuato, México: Intagri. Celaya.

Castillo, F. S. D.; Durán Paredes, M.; Moreno Pérez, E. D. C.; Magdaleno Villar, J. J. (2017). Variedades y densidades de población de frijol ejotero cultivado bajo invernadero e hidroponía. Revista mexicana de ciencias agrícolas. 8(5): 1187-1193.

Castañares, J. L. (2020). El ABC de la Hidroponía. Recovered from https://repositorio.inta.gob.ar/ bitstream/handle/20.500.12123/8023/INTA_ DireccionNacional_EEAAMBA_Casta\%C3\%B1ares_ JL_ABC_de_la_hidroponia.pdf?sequence $=1$

Chaves, F; Alvarado. F. (2012). Cisticercosis cerebral. Análisis de lesiones anatomopatológicas, principales datos clínicos, epidemiológicos y revisión de literatura. Recovered from http://www. binasss.sa.cr/revistas/neuroeje/v6n2/art4.pdf

Donoso, C. (1992). Ecología forestal. Valdivia, Chile: Editorial Universitaria. 27p.

Demchak, K.; Elkner, C.; Esslinger, M.; Frazier, S.; Guiser, J.; Halbrendt, J.; Harper, G.; Krawczyk, K.; Richards, J.; Heckman, B.; Majek, P.; Nitzsche, P.; Oudemans, G.; Pavlis, D.; Polk, C.; Rodriguez-Saona, W.; Sciarappa, D.; Ward, G.; Johnson, B.; Butler, J.; Fiola, W.; Lantz, M.; Ehlenfeldt, J.; Derr, C.; Johnson, D.; Pfeiffer, R.; Straw, K.; Yoder, A.; Biggs, J.; Jett, L.; Jett, E.; Mashburn, H. ; Swarz, V. (2013). Strawberry. En: The Mid Atlantic Berry Guide for Commercial Growers, 2013-2014. pp. 49-114. Primera edición. Penn State: The Pennsylvania State University. 284p.

Florez, R; Mora, R. (2010). Innovación y Transferencia tecnológica en el marco de la estrategia agroindustrial de Bogotá y Cundinamarca. En: Bonilla, C.; Flórez. R.; Mora. R. Fresa (Fragaria ananassa Duch) producción y manejo poscosecha. Produmedios, producción de medios de comunicación. pp. 04-116. Primera edición. Bogotá, Colombia: Corredor Tecnológico Agmoindustrial, Cámara de Comercio de Bogotá. 114p.

Garcia, H.; Gonzalez, A.; Rodriguez, S.; Gonzalvez, G.; Llanos-Zavalaga, F.; Tsang, V. (2010). Epidemiology and control of cisticercosis. Revista Peruana de 
Medicina Experimental y Salud Pública. 27(4):592597.

Gonzales-Murillo, C.; Quintero, M.; Meneses, V. (2005). Determinación de algunas propiedades hidrofisicas de los sustratos utilizados en cultivos de flores en la sabana de Bogotá. En: Flórez, V.; Fernández, A.; Miranda, D.; Chávez, B.; Guzmán, J. Avances sobre fertirriego en la floricultura colombiana. pp: 427449. Bogotá: Universidad Nacional de Colombia.

Guerrero, E.; Revelo, J.; Benavides, 0. Chaves, G.; Moncayo, C. (2014). Evaluación de sustratos en un cultivo de lechuga bajo un sistema hidropónico en el municipio de Pasto. Recovered from https:// revistas.udenar.edu.co/index.php/rfacia/article/ download $/ 1933 / 4289$ ?inline $=1$

Gutiérrez-Castorena, M.A.; Hernández, J.; Ortiz, C.; Anicua-Sánchez, R.; Hernández, M.A. (2011). Relación porosidad-retención de humedad en mezclas de sustratos y su efecto sobre variables respuesta en plántulas de lechuga. Revista Chapingo Serie Hortícola. 17(3): 183-196.

Hang, S. (2014). Curso Edafología. Recovered from https://blog.ucc.edu.ar/edafologia/files/2014/08/ Teorico-2_Propiedades-fisicas_ucc_14.pdf

Hancock, J.; Sjulin, T.M.; Lobos, G.A. (2008). Strawberries. En: Hancock, J. Temperate fruit crop breeding: Germplasm to genomics. pp. 393-437. Dordrecht, The Netherlands: Academic Publishers.

Hernández, E.J.L. (2009). Propiedades Hídricas en Mezclas de Sustratos con Diferentes Proporciones y Tamaños de Partícula. Recovered from https://1library.co/document/dzxvg04ypropiedades-hidricas-mezclas-sustratosdiferentes-proporciones-tamanos-particula.html

Hiller, D. (1998). Environmental Soil Physics. San Diego, C.A: Academic Press. 771p

Horn, R.; Baumgartl, T. (2000). Dynamic properties of soils. In: Sumner, M. Handbook of Soil Science. pp: 19-46. Washington, D.C: CRC Press. 1519p.

ICA-Instituto Colombiano Agropecuario. (2009). Mis Buenas Prácticas Agrícolas "Guía para agroempresarios". Bogotá, Colombia: ICA.
Jiménez, A. P. (2015). La Hidroponía como una estrategia de Acción Social en la Escuela de Estudios Generales de la Universidad de Costa Rica. Estudios. 30: 489-519.

Lemaire, F. (1995). Physical, chemical and biological properties of growing medium. Acta Horticulture. (39): 273-284.

Llanos, P. (1988). Manual hidropónico. Bogotá: Ed. Diario del Agro. 30p

Martínez, J.; León, H. (2014). Producción de fresa en invernadero. Recovered from https://es.slideshare. net/bryantdanniel/la-produccion-fresa-eninvernadero

Massa, D. ; Incrocci, R.; Maggini, G. ; Carmassi, C. ; Campiotti, A.; Pardossi, A. (2010). Strategies to decrease water drainage and nitrate emission from soilless culture of greenhouse tomato. Agriculture Water Management. 97: 971-980.

Meneses, V. (2004). Evaluación del comportamiento hidráulico de cuatro líneas de goteo y diferentes sustratos utilizados en el cultivo hidropónico del clavel. Bogotá: Universidad Nacional de Colombia.16p.

Molina, E. (2018). Fertilización de fresa. Recovered from http://www.cia.ucr.ac.cr/pdf/Memorias/ FERTILIZACION\%20DE\%20FRESAS\%202018.pdf

OR, D.; Wraigth, J. M. (2000). Soil water content and water potentional relationships. In: Summer, M. Handbook of soil Science. pp: 53-83. Wastington, D.C: CRC press.

Orozco, R.; Marfa, 0.; Burés, S. (1995). Water status of graded perlites. Acta Hort. 401: 137-144.

Pape, T.; Lagger, D. (1994). Manual for soil descriptions and classification. Wageningen, The Netherlands: Wageningen Agricultural University. 15p.

Quintero, C. (2004). Determinación de las curvas de retención de humedad para sustratos usados en cultivos de flores en la Sabana de Bogotá. Bogotá: Universidad Nacional de Colombia. 16p. 
Quintero, M. F.; González-Murillo, C.A.; Flórez, V. J. (2006). Evaluación de las características hidrofísicas de los sustratos cascarilla de arroz quemada, fibra de coco y sus mezclas. En: Flórez, V.; Fernández, A.; Miranda, D.; Chávez, B.; Guzmán, J. Avances sobre fertirriego en la floricultura colombiana. Bogotá: Universidad Nacional de Colombia. 451p.

Quintero, M. F.; Valenzuela M.; Guzmán. (2012). Evaluacion de sustratos alternativos para el cultivo del miniclavel (Dianthus carypholus). Revista Colombiana de Ciencias Hortícolas. 6(1): 76-87. doi: http://dx.doi.org/10.17584/rcch.2012y6i1.1281

Rubio, A. (2010). La densidad aparente en suelos forestales del parque natural Los Alcornocales. Sevilla: Universidad de Sevilla. 27p.

Torres, A.; Camberato, D.; Lopez, R.; Mickelbart, M. (2000). Medición de pH y conductividad eléctrica en sustratos. Recovered from https://www.extension. purdue.edu/extmedia/ho/ho-237-sw.pdf

Tüzel, I.; Tunali, U.; Tüzel, Y.; Öztekin, G. (2009). Effects of salinity on tomato in a closed system. Acta Horticultura. 807: 457462.

Van-0s, E. (2009). Comparison of some chemical and non-chemical treatments to disinfect a recirculating nutrient solution. Acta Horticultura. 843:229-234.

Vence, B. (2008). Disponibilidad de agua-aire en sustratos para plantas. Ciencia del Suelo. 26: 105114.

Verdonck, 0.; Demeyer, P. (2004). The Influence of the particle sizes on the physical properties of growing media. Acta Horticulture. 644: 99-101. 